Original Research Article

\title{
Efficacy of topical phenytoin in healing diabetic foot ulcer
}

\author{
Anand Vardhan ${ }^{1}$, Pooja Garg ${ }^{2}$, Vijay Kumar Sehgal ${ }^{3}$, C. Dinesh Naidu', Mangesh Bankar ${ }^{1}$, \\ Sushil Mittal ${ }^{4}$
}

${ }^{1}$ Department of Pharmacology, Andaman and Nicobar Islands Institute of Medical Sciences

Port Blair, India

${ }^{2}$ Department of Pathology, Andaman and Nicobar islands Institute of Medical Sciences Port Blair

${ }^{3}$ Department of Pharmacology, Government Medical College, Patiala, Punjab, India

${ }^{4}$ Department of Surgery, Government Medical College, Patiala, Punjab, India

Received: 11 September 2016 Accepted: 12 October 2016

*Correspondence to:

Dr. Anand Vardhan,

Email: varanand.26@gmail.com

Copyright: (C) the author(s), publisher and licensee Medip Academy. This is an openaccess article distributed under the terms of the Creative Commons Attribution NonCommercial License, which permits unrestricted noncommercial use, distribution, and reproduction in any medium, provided the original work is properly cited.

\begin{abstract}
Background: India is fast becoming world diabetes capital. Complications are a cause of hospitalization in patients with diabetes mellitus especially foot complications. Gauze moistened with saline has been the standard method.

Methods: The study was done from June 2015 to June 2016. The objective of this study was to assess the efficacy of topical phenytoin compared to standard and conventional methods of wound care in improving the healing process. In this randomised control trial, the data from 70 patients with diabetic ulcers was collected, 35 patients underwent topical phenytoin dressing while remaining 35 underwent conventional wound care. Histopathological and Clinical examination were done and the following parameters were calculated: Granulation tissue formation in 2 weeks and Mean duration of hospital stay.

Results: In this study, Mean hospital stay in days was 33.4 in Phenytoin treated group and in other group with use conventional materials, the mean hospital stay in days was 39.7 days. Granulation tissue formation was faster as compared to conventional materials of Dressings.

Conclusions: In this study we conclude Topical phenytoin helps in faster healing of Diabetic Foot Ulcers and it also reduces the mean hospital stay of the patients.
\end{abstract}

Keywords: Diabetic foot, Standard and conventional normal saline dressing, Topical phenytoin

\section{INTRODUCTION}

Diabetes is a disease of modern era and India is marching toward to be the capital of diabetes. India has a lot of diabetic patients. Total world has $7 \%$ of the population with diabetes. India followed by China and USA on the top amongst diabetic country list. ${ }^{1}$ Diabetic foot syndrome is a most common and preventable complication of diabetes. About $15 \%$ of diabetic individual will develop diabetic foot syndrome in their life time. ${ }^{2}$ Diabetic foot ulcer precedes maximum number of amputation in individuals. This can be related to many social and cultural patterns in India such as lack of knowledge and facility for adequate diabetic care, poverty, and other socioeconomic conditions. ${ }^{3}$ The optimal topical therapy for DFU remains ill-defined. Gauze moistened with saline has been the standard method; however, it is difficult to maintain a moist wound environment continuously. Subsequently, various wound gels, growth factors, enzymes causing debridement, hyperbaric oxygen therapy, cultured skin substitutes, and other wound therapies have been put forward. All of these therapies are associated with significant cost and are being used in some situations without sufficient evidence in favour of their efficacy. ${ }^{4}$

Phenytoin as a topical application is used in many studies on ulcers caused by diabetic, and it is seen to stimulate 
the granulation tissue formation within 2-7 days. The antibacterial activity of phenytoin is against Staphylococcus aureus, Escherichia coli, Klebsiella, and Pseudomonas. ${ }^{5}$ Phenytoin results in proliferation of fibroblasts, collagen deposition, new blood vessel formation, promotes granulation tissues formation, reduces the collagenase action, and bacterial contamination. ${ }^{6}$ However, there are some contradictory reports on the use of phenytoin as topical agent. ${ }^{7}$

The present study was conducted to assess the effect of topical phenytoin used as dressing with comparison to conventional moist wound dressing in the healing of diabetic ulcers and to see that whether it is better in the management of diabetic ulcers.

\section{METHODS}

A randomised control, open label trial was conducted in which 70 patients with diabetic foot ulcers admitted in the Department of Surgery in Government Medical College Patiala, were enrolled in this study after obtaining written informed Consent and ethical approval from Institutional ethical committee. The inclusion and exclusion criteria are as follows:

\section{Inclusion criteria}

Patients with chronic ulcers with non-insulin dependent diabetes mellitus.

\section{Exclusion criteria}

- Chronic non-healing wounds caused by other ailments

- Diabetes mellitus with gangrenous changes

- Wounds with bone pathology

- Other co-morbid conditions like renal failure, other immunocompromised states and other factors, which adversely affect wound healing

A total of 70 patients with diabetic foot ulcers satisfying all the inclusion criteria mentioned above were included in the study. Data collected was entered in the Case Record Forms (CRF) after obtaining the written informed consent. The patients were divided randomly in study and the control group. The study group included the patients with wound care done with topical phenytoin therapy while control group patients were subjected to conventional wound care. After detailed clinical examination and relevant investigations, wounds were thoroughly debrided under anesthesia and the ulcer size as well as the surface area was assessed immediately after surgical debridement. Reassessment of the same was done after 10-14 days in both groups. Dressings were changed once daily in both groups. A $100 \mathrm{mg}$ phenytoin sodium capsule was mixed in normal saline and applied locally and wound was covered with aseptic precautions. Conventional Dressing was done with 5\% Betadine (Povidone-Iodine) solution. Daily monitoring of blood sugar was done and accordingly appropriate treatments were provided. Statistical Analysis was done using ChiSquare test and $\mathrm{p}$ value was calculated.

\section{RESULTS}

Table 1: Gender wise distribution of the patients.

\begin{tabular}{|llll|}
\hline $\begin{array}{l}\text { Treatment } \\
\text { Group }\end{array}$ & Gender & $\begin{array}{l}\text { No. of } \\
\text { patients }\end{array}$ & Total \\
\hline $\begin{array}{l}\text { Group1 } \\
\text { (Phenytoin) } \\
\mathrm{n}=35\end{array}$ & Male & 22 & \multirow{2}{*}{35} \\
\cline { 2 - 3 } & Female & 13 & \\
\hline $\begin{array}{l}\text { Group2 } \\
\text { Conventional) } \\
\mathrm{N}=35\end{array}$ & Male & 18 & 35 \\
\cline { 2 - 3 } & Female & 17 & \multirow{2}{*}{3} \\
\hline
\end{tabular}

Table 1 shows the Gender wise distribution of the patients which were allocated the 2 groups that is group1 includes the patients who were treated with phenytoin topical preparation and includes 22 male and 13 female patients and Group2 includes the patients who were treated with the Conventional Dressings and includes 18 male and 17 female patients.

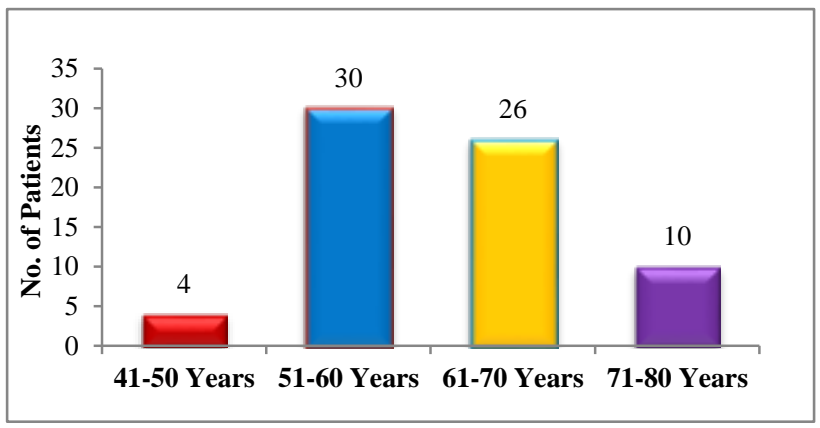

Figure 1: Age wise distribution of the patients.

Figure 1 shows the age wise distribution of the patients in this study. 30 patients were having foot complications of Diabetes in this study followed by the age group of 61-70 years having 26 patients, followed by the age group of 71-80 years age group having 10 patients and the least affected group with foot complications of diabetes mellitus was 41-50 years age group having 4 patients.

Table 2: Distribution of patients based on duration of hospital stay.

\begin{tabular}{|llll|}
\hline $\begin{array}{l}\text { Treatment } \\
\text { groups }\end{array}$ & $\begin{array}{l}\text { Mean } \\
\text { hospital stay } \\
\text { (in Days) }\end{array}$ & $\begin{array}{l}\text { Standard } \\
\text { deviation }\end{array}$ & p value \\
\hline $\begin{array}{l}\text { Group 1 } \\
\text { (Phenytoin) } \\
\mathrm{n}=35\end{array}$ & 33.4 & 3.12 & $<0.05$ \\
\hline $\begin{array}{l}\text { Group 2 } \\
\text { (Conventional) } \\
\mathrm{n}=35\end{array}$ & 39.7 & 4.39 & $<0.05$ \\
\hline
\end{tabular}


Table 2 shows the distribution of patients based on their Hospital stay and in Group1 patients who were treated with topical Phenytoin the Mean hospital stay in days was 33.4 with a standard deviation of 3.12 days.
Similarly in Group 2 patients who were treated with conventional method the mean hospital stay in days was 39.7 with a standard deviation of 4.39 days and the $p$ value was $<0.05$ which was statistically significant.

Table 3: Distribution of patients based on the histopathological and clinical examination findings after 2 weeks of treatment.

\begin{tabular}{|l|ccc|}
\hline Treatment groups & $\begin{array}{l}\text { Histopathological and clinical findings of } \\
\text { healthy granulation tissue in mean percentage }\end{array}$ & Standard deviation & p value \\
\hline Group 1 (Phenytoin) $\mathrm{n}=35$ & $89.2 \%$ & 3.2 & $<0.05$ \\
\hline Group 2 (Conventional) $\mathrm{n}=35$ & $73.9 \%$ & 5.3 & $<0.05$ \\
\hline
\end{tabular}

\section{Table 4: Comparison of various studies with this study.}

\begin{tabular}{|c|c|}
\hline Name of Study & Results/ Conclusion \\
\hline Vardhan A et al & $\begin{array}{l}\text { Phenytoin topical dressing decreases Hospital Stay and help in granulation tissue formation } \\
\text { much earlier than conventional dressings and hence it is better than Conventional dressing } \\
\text { with saline and Povidone - iodine. }\end{array}$ \\
\hline Muthukumarswamy et $\mathrm{al}^{5}$ & Mean healing Time Better in phenytoin treated group than conventional methods. \\
\hline Pendse et al ${ }^{12}$ & $\begin{array}{l}\text { Phenytoin has significant antibacterial properties. } 50 \% \text { wounds treated with phenytoin had } \\
\text { negative bacterial culture on } 7 \text { th day of treatment, where as in the control group only } 17 \% \text { had } \\
\text { negative culture. }\end{array}$ \\
\hline Anstead et al ${ }^{13}$ & $\begin{array}{l}\text { Phenytoin has promoted healing in a massively necrotized Grade IV decubitus ulcer not } \\
\text { responding to any other therapy. }\end{array}$ \\
\hline DaCosta et $\mathrm{al}^{6}$ & $\begin{array}{l}\text { Phenytoin enhances the fibroblast infiltration with } \\
\text { neovascularization and } 2647 \text { ignify cantly increases the tensile strength of healed wounds. }\end{array}$ \\
\hline Pai et $\mathrm{al}^{14}$ & Good granulation tissue with topical phenytoin. \\
\hline Tauro LF et al ${ }^{15}$ & $\begin{array}{l}\text { Phenytoin aids in faster healing of diabetic wounds with better graft take up and decreased } \\
\text { hospital stay. }\end{array}$ \\
\hline Jayalal JA et $\mathrm{al}^{16}$ & $\begin{array}{l}\text { Enhanced wound healing and sense of well-being in individuals with diabetic foot ulcer } \\
\text { treated with topical application of phenytoin than the other classical wound dressing materials. }\end{array}$ \\
\hline
\end{tabular}

Table 3 shows the distribution of patients based on their histopathological and clinical examination after 2 weeks of treatment completion. In Group1 patients Healthy granulation tissue a seen in mean $89.2 \%$ patients with a standard deviation of 3.2 and in Group 2 patients healthy granulation tissue was seen in Mean $73.9 \%$ Patients with a standard deviation of 5.3 and both the groups had $p$ value of $<0.05$ which is statistically significant.

\section{DISCUSSION}

Phenytoin is under investigation as a treatment for more than 100 diseases. Numerous allergy and proliferative, idiosyncratic cutaneous side effects have been reported with its use. ${ }^{8}$ A frequent observed and unwanted side effect of phenytoin, is gingival (Gum) hyperplasia, especially in children. ${ }^{9}$ Phenytoin promotes wound healing by following mechanisms: fibroblast proliferation, enhanced and rapid formation of granulation tissue, decreasing collagenase activity, glucocorticoid activity inhibiting, antibacterial activity by affecting inflammatory cells, neovascularisation and phenytoin increases gene expression of the platelet derived growth factor $\beta$ chain in macrophage and monocytes. 10,11

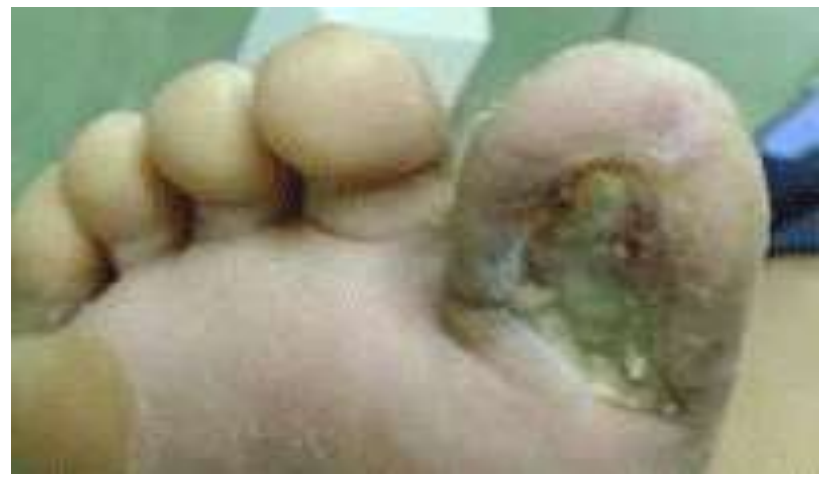

Figure 2: A case of diabetic foot ulcer at the time of admission in surgery ward of government medical college, Patiala.

In this study conducted in Government Medical College Patiala it was seen that mean hospital stay in days was less as compared to conventional treatment methods and 
healthy granulation tissue after 2 weeks of treatment was seen in more patients treated with Phenytoin group as compared to conventional Dressing materials.

\section{A case of diabetic foot ulcer}

Figure 2 - 4 shows a 51 year old male patient admitted in Government medical college Patiala showing improvement after 2 weeks of treatment.

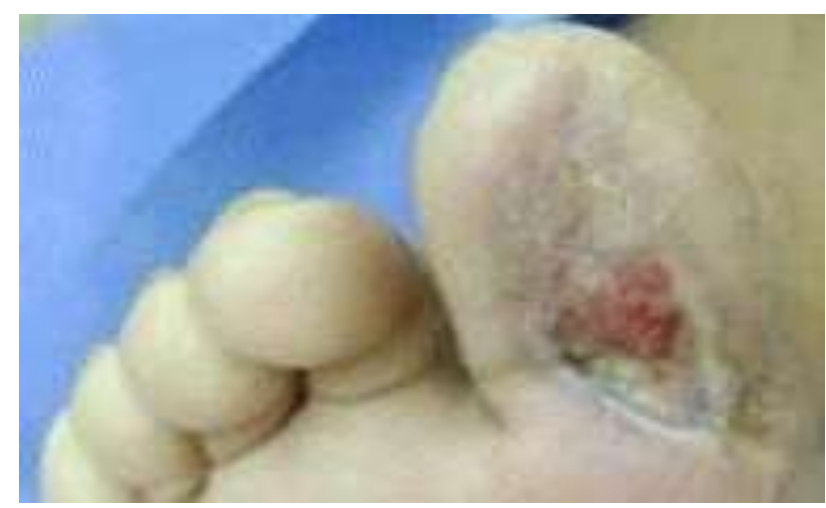

Figure 3: The same case after 2 weeks of topical phenytoin dressing showing improvement with decreased slough and healthy granulation tissue formation.

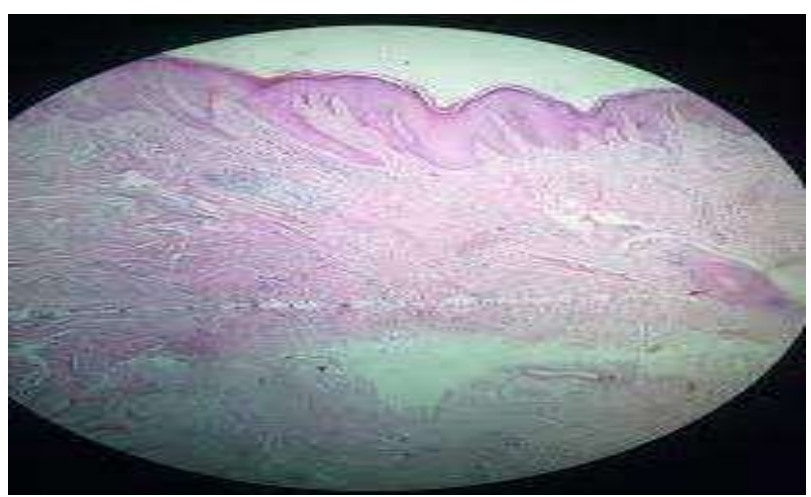

Figure 4: Histopathological examination of the skin sample after 2 weeks of treatment showing healthy granulation tissue formation.

\section{CONCLUSION}

This prospective randomized control study shows enhanced wound healing and sense of well-being in individuals with diabetic foot ulcer treated with topical application of phenytoin than the conventional agents like use of normal saline and povidone-iodine in the wound dressings.
Funding: No funding sources Conflict of interest: None declared

Ethical approval: The study was approved by the Institutional Ethics Committee

\section{REFERENCES}

1. Kaveeshwar SA, Cornwall J. The current state of diabetes mellitus in India. AMJ. 2014;7:45-8.

2. Pendsey SP. Understanding diabetic foot. Int J Diabetes Dev Ctries. 2010;30:75-9.

3. Viswanathan V, Shobhana R, Snehalatha C, Seena R, Ramachandran A. Need for education on footcare in diabetic patients in India. J Assoc Physicians India. 1999;47:1083-5.

4. White R, McIntosh C. Topical therapies for diabetic foot ulcers: standard treatments. J Wound Care. 2008;17:42632.

5. Muthukumarasamy MG, Sivakumar G, Manoharan G. Topical phenytoin in diabetic foot ulcers. Diabetes Care. 1991;14:909-11.

6. DaCosta ML, Regan MC, al Sader M, Leader M, BouchierHayes D. Diphenylhydantoin sodium promotes early and marked angiogenesis and results in increased collagen deposition and tensile strength in healing wounds. Surgery. 1998;123:287-93.

7. Shaw J, Hughes CM, Lagan KM, Stevenson MR, Irwin CR, Bell PM. The effect of topical phenytoin on healing in diabetic foot ulcers: A randomized controlled trial. Diabet Med. 2011;28:1154-7.

8. Meritt HH, Putnam TJ. Sodium diphenyl hydantoinate in the treatment of convulsive disorders, JAMA. 1938;111:1068-73.

9. Bethedsa M.D., 2001, ASHP drug information 2001, American Society of Health System Pharmacists, 2081.

10. Genever PG, Cunliffe WJ, Wood EJ. Influence of the extracellular matrix on fibroblast responsiveness to phenytoin using in vitro wound healing models. $\mathrm{Br} \mathrm{J}$ of Dermatol. 1996;133:231-5.

11. Dill RE, Miller EK, Weil T, Lesley S. Phenytoin increases gene expression for platelet - derived growth factor in $\beta$ chain in macrophages and monocytes. $\mathrm{J}$ peridontol. 1993;64:169-73.

12. Pendse AK, Sharma A, Sodani A, Hada S. Topical phenytoin in wound healing. Int J Dermatol. 1993;32:2147.

13. Anstead GM, Hart LM, Sunahara JF, Liter ME. Phenytoin in wound healing, Ann Pharmacol. 1996;30:768-75.

14. Pai MR, Sitaram N, Kotian MS. Topical phenytoin in diabetic ulcers: A double blind controlled trial, Indian J Med Sci. 2011;55:593-9.

15. Tauro LF, Shetty P, Dsouza NT. A comparative Study of Efficacy of Topical Phenytoin vs Conventional Wound Care in Diabetic Ulcers. International Journal of Molecular Medical Science. 2013;3(8).

16. Jayalal JA, Kumar SJ, Dhinesh, Thambithurai D, Kadar JMA. Efficiency of Topical Phenytoin on Healing in Diabetic Foot Ulcer: A Randomized Controlled Trial. Int J Sci Stud. 2015;3(3):84-9.

Cite this article as: Vardhan A, Garg P, Sehgal VK, Naidu CD, Bankar M, Mittal S. Efficacy of topical phenytoin in healing diabetic foot ulcer. Int J Basic Clin Pharmacol 2016;5:2645-8. 